\title{
Information Communication Technology (ICT) for Disabled Persons in Bangladesh: Preliminary Study of Impact/Outcome
}

\author{
Md. Jahangir Alam Zahid ${ }^{1}$, Md. Mahfuz Ashraf ${ }^{2}$, \\ Bushra Tahseen Malik ${ }^{1}$, and Md. Rakibul Hoque ${ }^{2}$ \\ ${ }^{1}$ Brainstorm Bangladesh, Road 28/K, House 08, Banani, Dhaka 1213, Bangladesh \\ jaz.zahid@gmail.com, bushra@brainstorm-bd.com \\ ${ }^{2}$ Dept. Management Information Systems, University of Dhaka, Bangladesh \\ mashraf@univdhaka.edu, rakibdu471@gmail.com
}

\begin{abstract}
To meet the need of digital inclusion and to mitigate the digital divide between disable and general people different ICT interventions are implemented in different developing and developed countries. But question arises to what extent these interventions are successful? Are these interventions are successful for creating new hope and confidence among disabled people? In this working paper we have tried to find the impact of these interventions from actual beneficiary perspectives. We have adopted Technology Acceptance Model (TAM) to know about perceived usefulness and perceived easiness from the disabled/visually impaired person's perspective. We found that though Technology has provided initial access to technology and information but the users are facing many challenges to overcome language barriers. Our ongoing study also reveals that social issues/variables are also important for getting acceptance of ICT interventions for disabled people.
\end{abstract}

Keywords: ICT, Disabled Persons, Development, Technology Acceptance Model (TAM), Thematic analysis, Bangladesh.

\section{Introduction}

The concept of Information Communication Technology (ICT) for developing courtiers comes in the 1990s when researchers identified "Digital Divide" as an important factor which is hindering developing countries to get the benefits of ICT interventions (Guillen, 2006; Servon, 2002). From 1990s to till now various researches are undertaken to measure digital divide and gradually various forms of digital divide emerged like divide between developed and developing countries, urban and rural area, rich and poor people, male and female etc (Nations, 2010; Hanimann \& Ruedin 2007, Norris, 2001; Mark, 2003). But most of the researchers have ignored one important aspect of digital divide that exist between general people and disabled people. Though few researches are 
undertaken regarding the issue but most of them have focused on technological perspective or supply side where they have tried to show how different technological innovations can increase the capability of disabled people (Bigham et al., 2008, Forgrave 2002, MacArthur 2009) which is parallel to thought of medical/individual model (Llewellyn and Hogan, 2000) where disability is regarded "patient" subject either to cure or to ongoing medical care. But today disabled concept is considered from social perspective (Tregaskis, 2002; Barnes and Mercer, 2005) which considers disabled as the "loss or limitations of opportunities that prevents people who have impairments from taking part in the normal life of the community on an equal level with others due to physical and social barriers."- (Cited in Finkelstein and French, 1993). So to consider the demand side i.e. the perception of disabled people regarding existing technology and to get the insight beyond technological perspective we have initiated a research on early 2011 which is still continuing.

In this working paper, we have attempted to investigate a preliminary outcome/impact of ICT interventions for disabled people from actual beneficiary perspective. We have used Technology Acceptance Model (TAM) to understand the outcome/impact of ICT interventions for disabled people in Bangladesh; one of the most densely populated developing countries in the World. Bangladesh is a small developing country with 150 million populations and according to one estimate almost 10 percent of total populations are disabled (BBS 2012).

The research will give an important insight for policymakers about the impact of ICT interventions from developing country as the research is not generalized in nature and has considered local context of Bangladesh. Besides the research is qualitative in nature and based on case study which will make an important contribution by understanding complex context of disabled people and by providing holistic, in-depth investigation (Zaina, 2007). In our research qualitative and case study technique will make significant contribution as in the last 20 years qualitative research has developed new principles to shed light on the complex interrelationships among physical impairment, societal barriers, and public programs (O'Day \& Killen 2002).

\section{Conceptual Framework of the Study: Technological Acceptance Model (TAM)}

Technology Acceptance Model (TAM) (Davis, 1989; Davis, Bagozzi \& Warshaw, 1989), originated in the Theory of Reasoned Action (TRA) (Fishbein \& Ajzen, 1975), offers a powerful explanation for user acceptance and usage behavior of information technology. According to TAM the use and benefits of a system largely depends on the motivation of actual user which is influenced by external factors and capabilities of a system. The model also says that the motivation of user depends on three factors (Figure-1) (a) Perceived ease of the system (b) Perceived benefits of the system (c) Attitude towards the system. According to Fred Davis (1989), attitude towards the system depends on Perceived ease of the 
system and Perceived benefits of a system, whereas perceived ease of use is defined as "the degree to which person believes that using a particular system would be free of effort" and Perceived benefits of a system defines the extent to which a person believed that a particular system will develop their life. These then lead to individual behavior intention and actual behavior. It is noted that perceived usefulness possess the strongest predictor of an individual's intention to use an information technology (Adams et al., 1992; Davis, 1989).

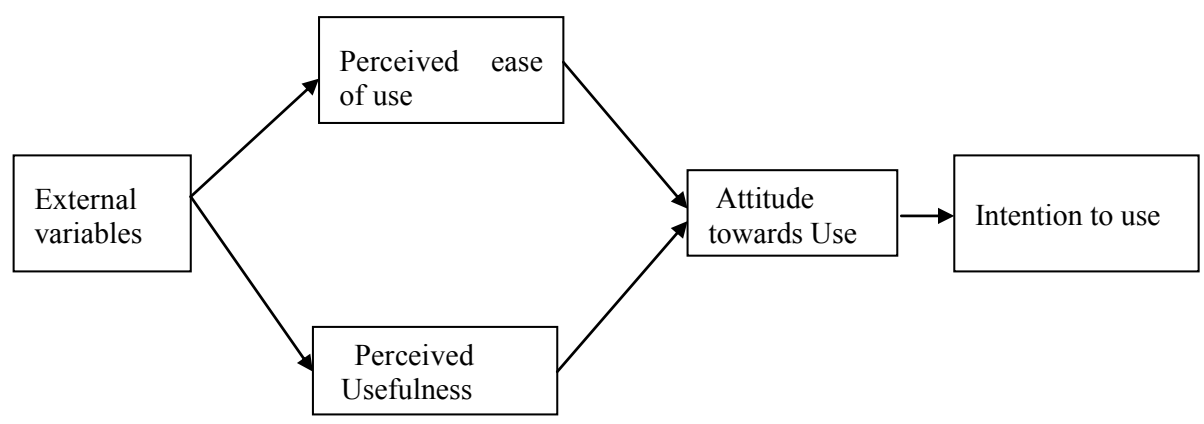

Fig. 1. Technology Acceptance Model (Davis,1989)

TAM also proposes that external factors affect intention and actual use through mediated effects on perceived usefulness and perceived ease of use. For measuring the perceived easiness Davis (1989) developed 10 criteria where focus is given on increasing quality of work, increasing quickness $\&$ control, effectiveness and quantity of works. Besides for measuring perceived usefulness Davis (1989) developed 6 criteria where focus is given on improving job performance, easiness and quicker performance. Though the paper enjoyed the benefits of TAM (Technology Acceptance Model) but an important limitation of TAM model is it ignores many external factors like age, education etc (Burton \& Hubona,2006).

\section{$3 \quad$ Methodology}

This research is exploratory and explanatory studies. A semi structured questionnaire was used to gather the information required for the study. Data was mainly gathered from 25 respondents from different ICT training centers for disable persons, university disable students and disabled job holders. The criteria's for understanding perceived usefulness and easiness are given in table-1. 
Table 1. Criteria used in the research to understand perceived usefulness and easiness from the disable persons' perspective

\begin{tabular}{|c|c|}
\hline \multirow{3}{*}{$\begin{array}{l}\text { Perceived } \\
\text { Usefulness }\end{array}$} & $\begin{array}{l}\text { - Economic: To what extent ICT will help them to obtain economic } \\
\text { freedom like: obtaining jobs, getting new source of income etc. }\end{array}$ \\
\hline & $\begin{array}{l}\text { - Social: To what extent ICT will help them to get new social identity } \\
\text { and respect like: new social network, social identity, perceived } \\
\text { importance in family and society. }\end{array}$ \\
\hline & $\begin{array}{l}\text { - Knowledge: To extent ICT will help disabled people to gather } \\
\text { knowledge from different sources. like: access to new paper, job circular, } \\
\text { study material. }\end{array}$ \\
\hline $\begin{array}{l}\text { Perceived } \\
\text { Easiness }\end{array}$ & $\begin{array}{l}\text { - Easy \& Understandable: To what extent disabled people believe that } \\
\text { existing ICT facility is easy and understandable for them. } \\
\text { - Flexibility \& Accessibility: Is the existing facility is flexible enough and } \\
\text { are the disabled people can access to all kinds of information sources? } \\
\text { - Controllability: how much control the disabled people have on the } \\
\text { existing facility? } \\
\text { - Effort: How much effort, both from physical and time perspective is } \\
\text { necessary for using the existing system? }\end{array}$ \\
\hline
\end{tabular}

Table 2. Key issues of respondents

\begin{tabular}{|l|l|}
\hline Title & \multicolumn{1}{|c|}{ Description } \\
\hline Software Used & JAWS (Job access with speech), Skype, AIM \\
\hline Profession & Masters students and Job holders \\
\hline Social Status & Middle class and lower middle class family members \\
\hline Place of living & $\begin{array}{l}\text { Origin is Rural Area and now currently living in Capita city for study and } \\
\text { Job purpose. }\end{array}$ \\
\hline Gender & 20 Male and 5 female. \\
\hline
\end{tabular}

\section{Preliminary Findings}

In case of perceived usefulness, most respondents believe that ICT or ICT training has increased their capability to compete in the increasingly complex technological work place as highlighted in another study by Hasselbring \& William (2000). According to respondents access and training to ICT has helped them to prepare draft, upload CV, searching jobs etc. But at the same time respondents are quite uncertain about their future job as most of the corporate bodies are still reluctant to recruit them. It is noteworthy of mentioning that corporate bodies are not confident about the capability of the Visual Impaired Person (VIP) persons (Frix \& Pal, 2010).

Our preliminary findings revealed that most of VIP persons either get the profession of teaching in computer learning center or in others jobs where little application of computer required. According to respondents though ICT has given them access in different application programs but in case of complex program like graphics design they are not doing well. These has raised the concern of further digital divide between disabled and competent people as competent people will adopt more 
easily with complex software programs and their capacity will enhance at an increasing rate than that of disabled people (Doh \& Stough 2010).

In case of knowledge perspective most of the respondents think that ICT has helped them to increase their knowledge by providing access to online based paper, study materials etc. Besides it has helped them to transfer recorded class lecture in computer and listen that with flexibility. Finally in case of social perspective most respondents believe that ICT has given them new social identity and reduce dependency in community, family and workplace.

In case of perceived easiness most respondents are satisfied with the existing platform for flexibility and controllability, however, local content is relatively limited. Hence they are unable to understand different computer training sessions in their own language. Another challenge identified by our participant was poor sound system of existing software/application.

\section{$5 \quad$ Conclusion and Future Work}

This working paper has attempted to find an early outcome or impact of ICT interventions for disabled in a developing country: Bangladesh by considering the actual beneficiary perspective. It considered the perception of disabled people looking at the social, economic, knowledge context as these issues are important in development research. We emphasized the study of particularization in the local context than generalization while understand the users perceptions. Our preliminary field data identified different themes through the lens of TAM. One of the major limitation of this study is we has to select literate disable person which actually represents very low proportionate of the entire disable population size in Bangladesh. In future, we will consider other forms of disabled people which may give a holistic view for ICT-enabled disable persons' benefit to the policymakers, NGO workers, academicians and researchers. We are also interested to evaluate how disabled people are adopting with changing technology and to what extent they are competent. In theoretical consideration, we are also interested to extend TAM considering the various social issues of the disable people. Further research will take more holistic view of disabled people with developed framework to generate new indicators for evaluating the ability of various kinds' disabled people to cope with changing technology and demands.

We conclude this working paper raising an important policy issue i.e. to what extent the policymakers, regulatory agencies and website builders are aware about disabled people, how much emphasize they have given to disabled people. This has again reemphasized our focus i.e. changing social attitude regarding disabled people.

\section{References}

Adams, D.A., Nelson, R.R., Todd, P.A.: Perceived Usefulness, Ease of Use, and Usage of Information Technology: A Replication. MIS Quarterly 16(2), 227-247 (1992)

Barnes, C., Mercer, G.: Disability, Work and Welfare: challenging the social exclusion of disabled people. Work Employment and Society 19(3), 527-545 (2005)

BBS, Bangladesh Bureau of Statistics, Government of Bangladesh (2012) 
Bigham, J.P., Prince, C.M., Ladner, R.E.: WebAnywhere: a screen reader on-the-go. In: Proceedings of the 2008 International Cross-Disciplinary Conference on Web Accessibility (W4A), pp. 73-82. ACM, Beijing (2008)

Burton-Jones, A., Hubona, G.S.: The mediation of external variables in the technology acceptance model. Information \& Management 43(6), 706-717 (2006)

Doh, S., Stough, R.R.: Analysis of the Impact of the Perceived Usefulness of ICT on the Digital Divide between Disabled and Non-disabled People in South Korea. International Review of Public Administration (IRPA) 14(3), 53-70 (2010)

Davis, F.D.: Perceived Usefulness, Perceived Ease Of Use, and User Acceptance of Information Technology. MIS Quarterly 13, 983-1003 (1989)

Davis, F.D., Bagozzi, R.P., Warshaw, P.R.: User Acceptance of Computer Technology: A Comparison of Two Theoretical Models. Management Science 35(8), 982-1003 (1989)

Finkelstein, V., French, S.: Towards a Psychology of Disability. In: Swain, J., Finkelstein, V., French, S., Oliver, M. (eds.) Disabling Barriers - Enabling Environments. Sage Publications, London (1993)

Fishbein, M., Ajzen, I.: Belief, Attitude, Intention and Behavior: An Introduction to Theory and Rresearch. Addison-Wesley, Reading (1975)

Forgrave, K.E.: Assistive technology: empowering students with learning disabilities. Clearing House 75, 122-126 (2002)

Frix, M., Pal, J.: A question of visibility: A rights-based look at ICT centers for persons with disabilities in Latin America. In: Proceeding of ICTD 2010 (2010)

Guillen, M.F.: Explaining the Global Digital Divide. Social Forces 84, 681-708 (2006)

Hanimann, T., Ruedin, E.: Digitale Gräben oder Digitale Brücken? Chancen und Risiken für Schwellenländer, http: / / eprints.rclis.org/11455/ (accessed)

Hasselbring, T., Williams-Glasser, C.: Use of Computer Technology to Help People with Special Needs. Children and Computer Technology 10(2), 102-122 (2000)

Llewellyn, A., Hogan, K.: The Use and Abuse of Models of Disability. Disability and Society 15(1), 157-165 (2000)

MacArthur, C.: Reflections on research on writing and technology for struggling writers. Learning Disabilities Research \& Practice 24(2), 93-103 (2009)

Warschauer, M.: Excellent Technology and Social Inclusion: Rethinking the Digital Divide. MIT Press, Cambridge (2003)

Nations, U. (ed.): United Nations E-Government Survey 2010 (2010)

Norris, P.: The Digital Divide: Civic Engagement. In: Information Poverty \& the Internet Worldwide, Cambridge Uni Press, Cambridge (2001)

O'Day, B., Killeen, M.: Research on the lives of persons with disabilities: The emerging importance of qualitative research methodologies. Journal of Disability Policy Studies 13, 9-15 (2002b)

Servon, L.J.: Bridging the Digital Divide: Technology, Community, and Public Policy. Blackwell, Oxford (2002)

Tregaskis, C.: Social Model Theory: the story so far... Disability and Society 17(4), 457-470 (2002)

Zainal, Z.: Case study as a research method. Jurnal Kemanusiaan bil. 9 (2007), http: / / eprints.utm.my/8221/1/ZZainal2007Case_study_as_a_Research.pdf (accessed on 21) 